\title{
Carbonate dual-phase improves the performance of single-layer fuel cell made from mixed ionic and semiconductor composite
}

\author{
S. Jouttijärvi ${ }^{1}$, X. Yao ${ }^{1,2,3}$, M. I. Asghar ${ }^{1,4^{*}}$, J. Etula ${ }^{5}$, A.-M. Reinecke ${ }^{6}$, W. Lippmann ${ }^{6}$ and P. D. Lund ${ }^{1 *}$ (1)
}

\begin{abstract}
A mixed ionic and semiconducting composite in a single-layer configuration has been shown to work as a fuel cell at a lower temperature $\left(500-600^{\circ} \mathrm{C}\right.$ ) than a traditional solid-oxide fuel cell. The performance of a single-layer fuel cell (SLFC) is often limited by high resistive losses. Here, a eutectic mixture of alkali-carbonates was added to SLFC to improve the ionic conductivity. The dual-phase composite ionic conductor consisted of a ternary carbonate (sodium lithium potassium carbonate, NLKC) mixed with gadolinium-doped cerium oxide (GDC). Lithium nickel zinc oxide (LNZ) was used as the semiconducting material. The LNZ-GDC-NLKC SLFC reached a high power density, 582 $\mathrm{mW} / \mathrm{cm}^{2}$ (conductivity $0.22 \mathrm{~S} / \mathrm{cm}$ ) at $600^{\circ} \mathrm{C}$, which is 30 times better than without the carbonate. The best results were obtained with the ternary carbonate which decreased the ohmic losses of the cell by more than 95\%, whereas the SLFC with a binary carbonate (sodium lithium carbonate, NLC) showed a lower conductivity and performance $\left(243 \mathrm{~mW} / \mathrm{cm}^{2}, 0.17 \mathrm{~S} / \mathrm{cm}\right.$ at $\left.600^{\circ} \mathrm{C}\right)$. It is concluded that adding carbonates to LNZ-GDC will improve the ionic conductivity and positively contribute to the cell performance. These results suggest a potential path for further development of SLFCs, but also imply the need for efforts on up-scaling and stability to produce practical applications with SLFC.
\end{abstract}

Keywords: Single-layer fuel cell, Ionic conductivity, Alkali carbonate mixture, Nanocomposites

\section{Introduction}

Single-layer fuel cell (SLFC) is an intriguing innovation that consists of one homogeneous mixed layer of an ionic conductor and a semiconductor. It has been shown to include all the necessary functionalities of a fuel cell in this single-layer [1-8], whereas conventional fuel cells, such as solid oxide fuel cells (SOFCs), require a threelayer structure with two electrodes and an electrolyte [9-11]. The SLFC utilizes nanocomposite materials and nano-redox reactions [1-3] and may operate below

\footnotetext{
* Correspondence: imran.asghar@aalto.fi; peter.lund@aalto.fi

${ }^{1}$ New Energy Technologies Group, Department of Applied Physics, Aalto University School of Science, Fl-00076 Aalto, Finland

Full list of author information is available at the end of the article
}

$600^{\circ} \mathrm{C}$, making it easier to fabricate and less prone to mechanical stresses. Also, the single-layer structure avoids interfacial resistances and chemical and thermal mismatches between the layers. Thus, the issues related to e.g. interfacial loss factors [12] are avoided. Schematics showing the structures and working principles of a three-layer fuel cell (SOFC as an example) and a SLFC are presented in Fig. 1.

The concept of SLFC was proposed by $\mathrm{He}$ et al. based on a perovskite material $\mathrm{La}_{0.9} \mathrm{Sr}_{0.1} \mathrm{InO}_{3-\delta}$, but a modest power density of $3 \mathrm{~mW} / \mathrm{cm}^{2}$ only was achieved due to low ionic conductivity $\left(<10^{-2} \mathrm{~S} / \mathrm{cm}\right)$ [4]. In 2011, Zhu et al. reported a breakthrough: $450 \mathrm{~mW} / \mathrm{cm}^{2}$ at $550{ }^{\circ} \mathrm{C}$ by using lithium nickel oxide (LN) and Gd-doped ceria 

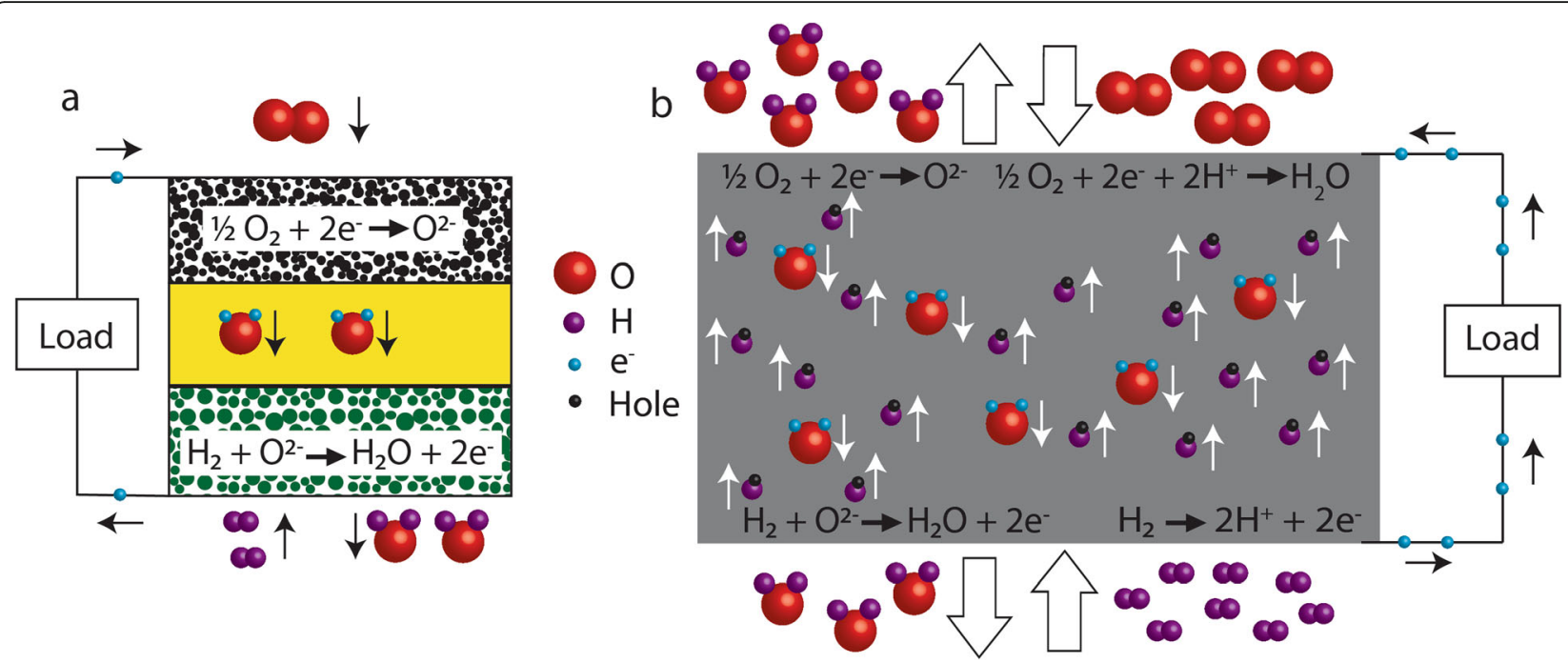

Fig. 1 Structure and working principle of a traditional three-layer solid oxide fuel cell (a). Working principle of a SLFC (b). Electrode reactions are also shown. Gas and particle flow directions are marked with arrows

(GDC) [5]. Since then, this design based on a mixture of a semiconductor and an ionic conductor has widely been utilized. Typical semiconducting materials include Liand Ni-based wide-bandgap oxides, such as LN [5], lithium nickel zinc oxide (LNZ) $[6,7,13]$, lithium nickel cobalt oxide [8], nickel zinc oxide [14], lithium nickel cobalt zinc oxide [15], lithium nickel cobalt zinc iron oxide [16] and lithum nickel cobalt aluminium oxide (NCAL) [17-19]. Also $\mathrm{CuFe}_{2} \mathrm{O}_{4}$ [20] and different perovskites, such as $\mathrm{La}_{0.6} \mathrm{Sr}_{0.4} \mathrm{Co}_{0.2} \mathrm{Fe}_{0.8} \mathrm{O}_{3-\delta}$ (LSCF) [21-24], $\mathrm{Ba}_{0.5} \mathrm{Sr}_{0.5} \mathrm{Co}_{0.8} \mathrm{Fe}_{0.2} \mathrm{O}_{3-\delta}$ (BSCF) [25] and $\mathrm{Pr}_{0.4} \mathrm{Sr}_{0.6} \mathrm{Co}_{0.2-}$ $\mathrm{Fe}_{0.7} \mathrm{Nb}_{0.1} \mathrm{O}_{3-\delta}[18]$ have been reported. The typical ionic conductors are based on doped ceria: GDC [5, 7, 15], Smdoped ceria (SDC) $[6,14,25-27]$, co-doped cerias [19, 21-23] and mixtures of doped ceria and alkali carbonates $[8,13,16-18,28,29]$ have been reported. The doped ceria - alkali carbonate mixture has been reported widely to improve the ionic conductivity of the electrolyte in threelayer fuel cells [30, 31]. The working mechanism of SLFC has been debated in the literature. Different junctions, such as p-n junction, Schottky junction, and bulk heterojunction has been suggested [6-8].

The highest power densities in the literature have been achieved with advanced ionic conductors: co-doped cerias or mixtures of a doped ceria and alkali carbonates. NCAL - (La, Pr, Nd co-doped ceria) has achieved $1187 \mathrm{~mW} / \mathrm{cm}^{2}$ [19], LSCF - (Ca, Sm co-doped ceria) 1080 and $1000 \mathrm{~mW} /$ $\mathrm{cm}^{2}$ in $[21,22]$ respectively and NCAL $-\left(\mathrm{Na}_{2} \mathrm{CO}_{3}-\mathrm{SDC}\right)$ $1072 \mathrm{~mW} / \mathrm{cm}^{2}$ at $550{ }^{\circ} \mathrm{C}$ [17]. With single-doped ceria, the power densities are lower: $600 \mathrm{~mW} / \mathrm{cm}^{2}$ with $\mathrm{Li}_{0.15} \mathrm{Ni}_{0.45} \mathrm{Zn}_{0.4} \mathrm{O}$ (LNZ) - SDC [6], $655 \mathrm{~mW} / \mathrm{cm}^{2}$ with BSCF-SDC [25], $741 \mathrm{~mW} / \mathrm{cm}^{2}$ with $\mathrm{Sm}_{0.5} \mathrm{Sr}_{0.5} \mathrm{CoO}_{3}-\mathrm{SDC}$ [26] and $841 \mathrm{~mW} / \mathrm{cm}^{2}$ with $\mathrm{Sr}_{2} \mathrm{Fe}_{1.5} \mathrm{Mo}_{0.5} \mathrm{O}_{6-\delta}-\mathrm{SDC}$ [27] have been reported at $550^{\circ} \mathrm{C}$.
In a recent work [7], the performance of a SLFC with LNZ-GDC material was enhanced from $357 \mathrm{~mW} / \mathrm{cm}^{2}$ to $801 \mathrm{~mW} / \mathrm{cm}^{2}$ at $550{ }^{\circ} \mathrm{C}$, when a non-catalytic Au current collector was changed to catalytically active NCALcoated Ni-foam. In that context it was found out that $\mathrm{H}^{+}$ dominated the ionic charge transfer process, while $\mathrm{O}^{2-}$ ions provided a minor contribution only. However, due to catalytic activity of NCAL, it is possible that the NCAL-coated Ni-foams acted as electrodes. Indeed, in $[32,33]$ devices with a semiconductor - ionic conductor layer sandwiched between two NCAL-coated Ni-foams were described as three-layer fuel cells without a traditional electrolyte.

To improve the performance of a SLFC, the resistive losses of the cell need to be reduced. Outgoing from the definition of the surface specific resistance $R \sim \sigma / L$, where $\sigma$ is the conductivity and $L$ the thickness of the SLFC, improving the conductivity or reducing the thickness of the layer will reduce the resistance of the cell. In this study, the conductivity was improved by adding alkali carbonates to GDC, creating a dual-phase ionic conductor. Alkali carbonates are known to show good ionic conductivity (both for $\mathrm{O}^{2-}$ and $\mathrm{H}^{+}$ions) above the carbonate melting point $[34,35]$.

The components in the composite may provide different ionic conduction pathways. The interface between the ceria and carbonate phases has been thought to provide a conducting pathway for $\mathrm{O}^{2-}[36,37]$. The SDC phase without carbonate shows negligible protonic $\left(\mathrm{H}^{+}\right)$ conductivity [37]. Adding $\left(\mathrm{Li}_{0.52} \mathrm{Na}_{0.48}\right)_{2} \mathrm{CO}_{3}$ carbonate, the proton conductivity increases above the melting point of the carbonate [38]. Even though the conducting path for $\mathrm{O}^{2-}$ and $\mathrm{H}^{+}$in the dual-phase composite electrolytes is not conclusive, the incorporation of the 
carbonate into the ceramic oxide indeed leads to rising ionic conductivity above the carbonate melting point $[36,39]$. In addition, the carbonates contribute to balancing the electronic and ionic conductivity in SLFC [28, 29]. In the SLFC field, typically a single carbonate, $\mathrm{Na}_{2} \mathrm{CO}_{3}$, has been added to the doped ceria $[8,13,16$, 17, 28]. Previous experiments with three-layer fuel cells have reported high ionic conductivities for binary $(>0.4$ $\mathrm{S} / \mathrm{cm}$ at $\left.600{ }^{\circ} \mathrm{C}\right)[40]$ and ternary $\left(>0.5 \mathrm{~S} / \mathrm{cm}\right.$ at $\left.600{ }^{\circ} \mathrm{C}\right)$ carbonates [41]. Thus investigating the effect of these carbonate mixtures to the SLFC performance deserves attention.

The aim of this study was to verify the benefits of applying eutectic binary and ternary alkali carbonates to SLFC in the temperarture range of $500-600^{\circ} \mathrm{C}$. The SLFC configuration utilized LNZ as a catalytic material, chosen based on previous studies and the simplicity of its synthetizing procedure $[6,7,13]$. The ionic conductor was based on GDC to which a ternary carbonate $\left(\mathrm{Na}_{2} \mathrm{CO}_{3}: \mathrm{Li}_{2} \mathrm{CO}_{3}: \mathrm{K}_{2} \mathrm{CO}_{3}\right.$, NLKC) or a binary carbonate $\left(\mathrm{Na}_{2} \mathrm{CO}_{3}: \mathrm{Li}_{2} \mathrm{CO}_{3}, \mathrm{NLC}\right)$ was added. The carbonates were eutectic mixtures, i.e. the mass ratios were chosen so that the melting temperature was minimized.

\section{Experimental}

\section{Material synthesis and manufacture of the SLFC}

All chemicals were acquired from Sigma-Aldrich and used as received unless otherwise stated. Mixing the powders in different steps was done in a planetary ball mill at $200 \mathrm{rpm}$ for $4 \mathrm{~h}$ using ethanol as solvent. LNZ was prepared by mixing lithium carbonate, nickel carbonate basic hydrate, and zinc nitrate hexahydrate in molar ratio 3:9:8 (Li:Ni:Zn). After mixing, the resulting powder was calcined at $800^{\circ} \mathrm{C}$ for $3 \mathrm{~h}$. The ternary carbonate NLKC was a eutectic mixture of $\mathrm{Na}_{2} \mathrm{CO}_{3}: \mathrm{Li}_{2} \mathrm{CO}_{3}$ : $\mathrm{K}_{2} \mathrm{CO}_{3}$ (mass ratio of 33.4:32.1:34.5 w- $\%$ and melting point $393{ }^{\circ} \mathrm{C}$ [41]). GDC-NLKC powder was prepared by mixing GDC and NLKC with a mass ratio of 7:3 and calcining at $600^{\circ} \mathrm{C}$ for $2 \mathrm{~h}$. LNZ-GDC-NLKC powder consisted of $40 \mathrm{w}-\%$ LNZ and $60 \mathrm{w}-\%$ GDC-NLKC and it was calcined at $700^{\circ} \mathrm{C}$ for $2 \mathrm{~h}$ after mixing. The LNZGDC-NLKC pellets $(\mathrm{d}=13 \mathrm{~mm})$ were prepared by pressing at $400 \mathrm{MPa}$ for $2 \mathrm{~min}$. Afterwards, the pellets were sintered at $700{ }^{\circ} \mathrm{C}$ for $2 \mathrm{~h}$. Gold paste was deposited on the pellets for improved current collection. The thickness of the LNZ-GDC-NLKC pellets (10 samples) was about $1 \mathrm{~mm}$.

For the LNZ-GDC-NLC cells, a modified recipe was used. Ball milling was done at $250 \mathrm{rpm}$ for $60 \mathrm{~min}$ in acetone, weight ratio of GDC and eutectic NLC (57:43 w- $\% \mathrm{Na}_{2} \mathrm{CO}_{3}: \mathrm{Li}_{2} \mathrm{CO}_{3}$, melting point $497^{\circ} \mathrm{C}[40]$ ) was $3: 1$, calcination was done for $60 \mathrm{~min}$ at $350^{\circ} \mathrm{C}$ and $600^{\circ} \mathrm{C}$ for GDC-NLC and LNZ-GDC-NLC respectively and the pellet pressing time was 5 min.
Figure $2 \mathrm{a}$ summarizes the manufacturing procedure used for the material synthesis.

\section{Electrochemical characterization}

The cells were installed in a fuel cell reactor (Fig. 2b-c) and heated to the operating temperature with a ramp of $5{ }^{\circ} \mathrm{C} / \mathrm{min}$. During the test, $\mathrm{H}_{2}(70 \mathrm{ml} / \mathrm{min})$ and air $(200$ $\mathrm{ml} / \mathrm{min}$ ) were supplied to two sides of the pellet as fuel and oxidant respectively (unless otherwise stated). Both current-voltage (IV) and electrochemical impedance spectroscopy (EIS) measurements were done with Zahner Zennium impedance unit. The EIS was performed under open circuit voltage (OCV) in a frequency range from $10^{5}$ to $0.1 \mathrm{~Hz}$ and $20 \mathrm{mV}$ amplitude. The aging test was done under OCV conditions with $\mathrm{H}_{2}$ supplied on one side and the air supplied on the other side of the cell.

\section{Microstructural characterization}

The SLFCs were characterized with a scanning electron microscope (FE-SEM, Zeiss Sigma VP) to study the cross-sectional image and surface properties of the cell. Transmission electron microscope (TEM), JEOL JEM2800 , was used to image the nanosized powder.

X-ray diffraction (XRD) was used for phase identification and grain size analysis of the powder, fresh pellet, and aged pellet. Rigaku SmartLab X-ray Diffractometer, equipped with a $9 \mathrm{~kW}$ rotating $\mathrm{Cu}$ anode $(0.154 \mathrm{~nm})$ and a HyPix-3000 2D single photon counting detector in 1D mode was used in parallel beam mode with a monochromator in $\theta / 2 \theta$ scan geometry. High-temperature XRD characterization was done with Rikagu SmartLab X-ray diffractometer and Ge-220 monochromator. Scan rate was $6 \% \mathrm{~min}$ for all these measurements. Prior to measurements, the powder samples were put on a Siplate and smoothened by pressing gently from above with another Si-plate.

\section{Results and discussion}

\section{Structure and morphology}

Figure 3a shows the cross-sectional view of the LNZGDC-NLKC pellet imaged by SEM. The pellet is about $1 \mathrm{~mm}$ thick and very dense, preventing effectively gas leakage through the cell. Figure $3 \mathrm{~b}$ shows a mixture of tightly packed nanoparticles surrounded with an amorphous carbonate phase. TEM images of the LNZGDC-NLKC powder (Fig. 3c-d) show nanoparticles of different sizes, varying roughly from $40 \mathrm{~nm}$ to $100 \mathrm{~nm}$. The very dark large objects in the TEM images are particle clusters that are too thick for electron transparency.

XRD-spectra of the powder, fresh pellet, and aged pellet are shown in Fig. 4 normalized to the GDC (111) peak intensity. Characteristic peaks of GDC and LNZ are clearly visible from the spectra (pellet spectra 
a

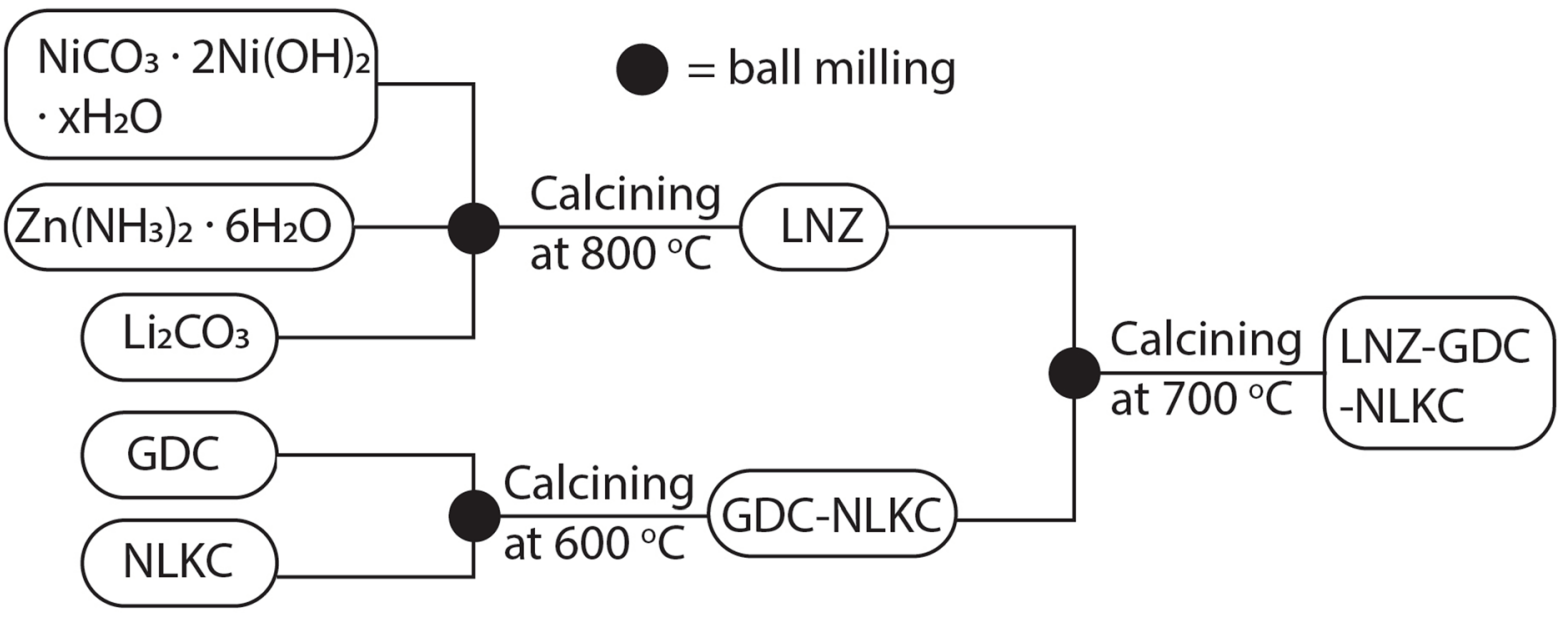

b

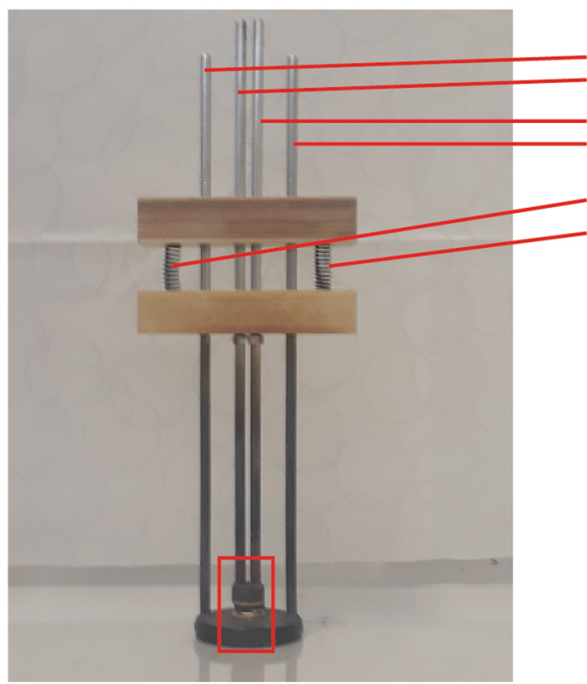

gas inlets gas outlets compressing springs fuel cell sealant rings

Fig. 2 A flowchart presenting the manufacturing procedure of the LNZ-GDC-NLKC material (a). Experimental setup used for electrochemical characterization (b). A zoom-in (c) of the area marked with a red rectangle in (b). The area inside the red ellipse (c) was covered by a hightemperature sealant flex

contains also Au from the current collector). The relative intensities of the LNZ peaks compared to the GDC peaks decrease when the pellet is aged. The intensity of the LiZnO peaks normalized to the GDC intensity decreases more than the intensity of the LiNiO peaks during aging. Additional peaks related to the alkali carbonates were not observed. This is consistent with the conclusions made based on the SEM images: the carbonates were in amorphous form and thus not visible in XRD-spectrum that shows only crystalline structures. Similar results have been obtained in the literature: the XRD-peaks related to the alkali carbonates are either very small compared to doped ceria or non-existing [13, $16,17,28,40,41]$.
Determined from the spectra, the size of GDC particles was $40-50 \mathrm{~nm}$ in powder form and $60-70 \mathrm{~nm}$ in both fresh and aged pellets. The size of LNZ components were $60-95 \mathrm{~nm}$ in powder and fresh pellet, reducing to $45-75 \mathrm{~nm}$ in aged pellets. The particles consisting of LiZnO seemed to be larger than the particles consisting of LiNiO. In case of powder, the calculated particle sizes are in the range of the particles seen in TEM images (Fig. 3c-d). The peaks were identified using ICDD files No. 04-015-2396 (GDC), 04-006-8078 (LiNiO) and 04-013-7260 (LiZnO) and Crystallography Open Database entry 9,008,463 (Au).

The characteristic peaks of the LNZ and GDC remained unchanged in the HT-XRD spectra shown in 


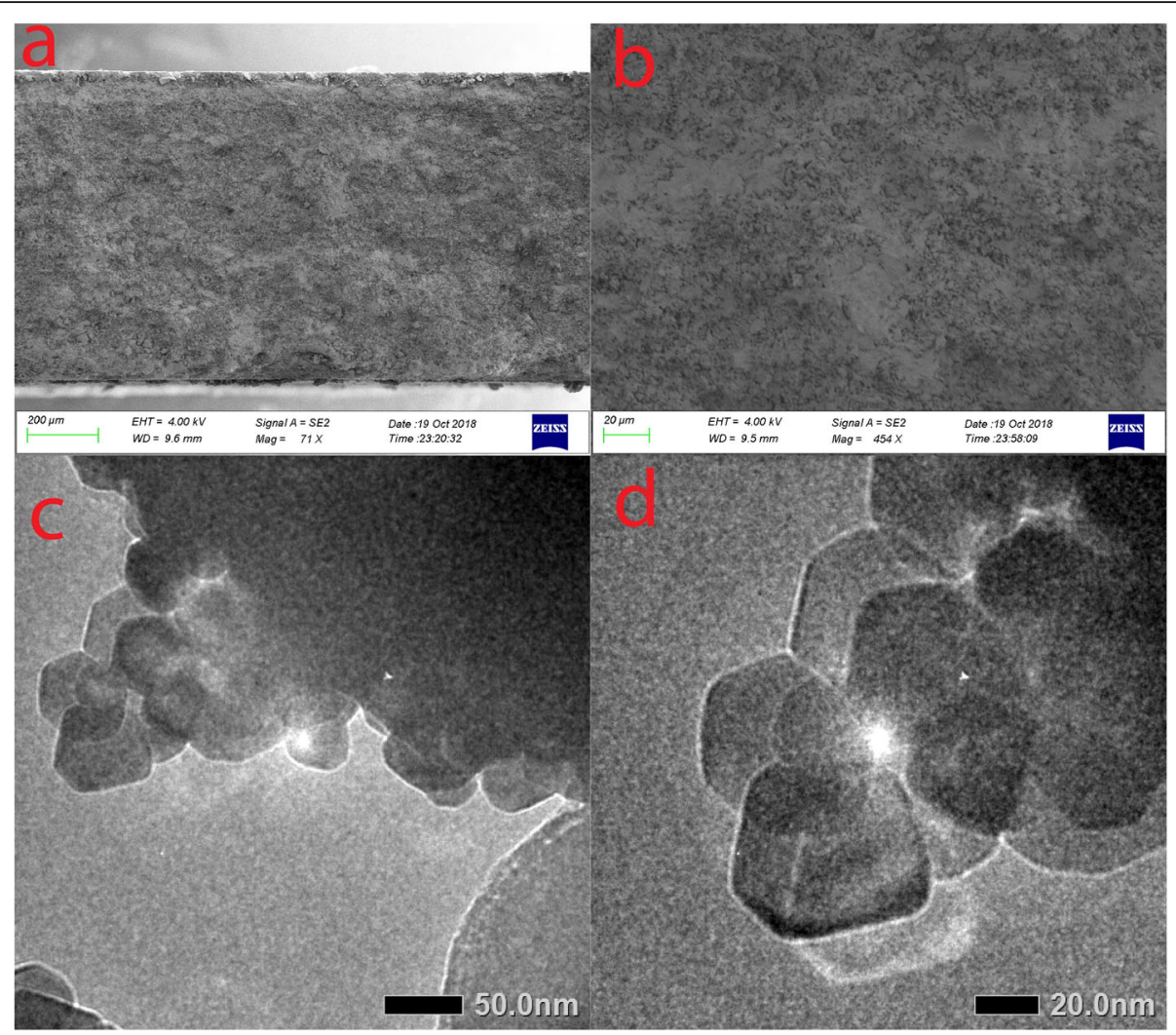

Fig. 3 Cross-section of the LNZ-GDC-NLKC pellet after the electrochemical measurements (a). A surface image showing the pxide and carbonate phases in the cell (b). TEM images of the LNZ-GDC-NLKC nanopowder with two different magnifications (c, d)

Fig. 5. This indicates that the crystalline structures of LNZ and GDC were stable at the operating temperature of the cells. A small peak shift towards lower angles was observed with all materials due to lattice expansion. The eutectic mixture of NLC undergoes a phase transformation at $497^{\circ} \mathrm{C}$ and the eutectic mixture of NLKC at $393^{\circ} \mathrm{C}$. These phase transformations have been recorded through differential scanning calorimetry [40, 41], but since the XRD signal from the amorphous carbonates is not visible, this does not affect to the XRD spectra. Furthermore, the molten carbonate phase did not affect the structural stability of the LNZ and GDC crystal structures.

\section{Electrochemical test with ternary carbonate}

Figure 6a shows the electrochemical performance of a SLFC at different temperatures with $\mathrm{H}_{2}$ and air as fuel and oxidant respectively. Due to the mixed electronic and ionic conductive characteristic of the single layer material, it is not disclosed that some loss in the OCV is due to electronic short-circuiting [28, 42]. An OCV of $0.75 \mathrm{~V}$ and maximum power density $\left(P_{\max }\right)$ of $352 \mathrm{~mW} /$ $\mathrm{cm}^{2}$ were obtained for the best test cell at $500{ }^{\circ} \mathrm{C} . P_{\max }$ increased with temperature, e.g. at $550{ }^{\circ} \mathrm{C} P_{\max }=510$
$\mathrm{mW} / \mathrm{cm}^{2}$, which is much higher than the respective value for pure LNZ-GDC material (shown in Figure S1). The main reason for this improvement is attributed to the enhanced ionic conductivity from the carbonate, which results in decreased ohmic losses in the cell. At $600^{\circ} \mathrm{C}, P_{\max }$ reached $582 \mathrm{~mW} / \mathrm{cm}^{2}$, which is higher than results reported in the literature including $150 \mathrm{~mW} / \mathrm{cm}^{2}$ at $650{ }^{\circ} \mathrm{C}$ [28], $312 \mathrm{~mW} / \mathrm{cm}^{2}$ at $550{ }^{\circ} \mathrm{C}$ [43] and $512 \mathrm{~mW} /$ $\mathrm{cm}^{2}$ at $600{ }^{\circ} \mathrm{C}$ [44]. The OCV is around $0.9 \mathrm{~V}$ at $600{ }^{\circ} \mathrm{C}$ and, contrary to expected behavior of $\mathrm{OCV}$ vis-à-vis temperature, the OCV increased here with increasing temperature. The same phenomenon has been observed in other studies with SLFC, e.g. with $\mathrm{Ce}_{0.8} \mathrm{Sm}_{0.2} \mathrm{O}_{2-\delta}$ (SDC) $-\mathrm{Na}_{2} \mathrm{CO}_{3}$ and $\mathrm{Sr}_{2} \mathrm{Fe}_{1.5} \mathrm{Mo}_{0.5} \mathrm{O}_{6-\delta}$ (SFM) [28]. The reason for this behavior could be in the enhancement of electronic and ionic conductivities, the catalytic activity of the functional electrodes and the carbonate in the SLFC. A preliminary study shows that the difference between the ionic conductivity and the electronic conductivity increases with increasing temperature (shown in Figure S2 and S3 in the Supplementary Information), which perhaps reduces the electronic losses in the cell, resulting in a higher OCV. A more systematic study would be necessary to explain the 


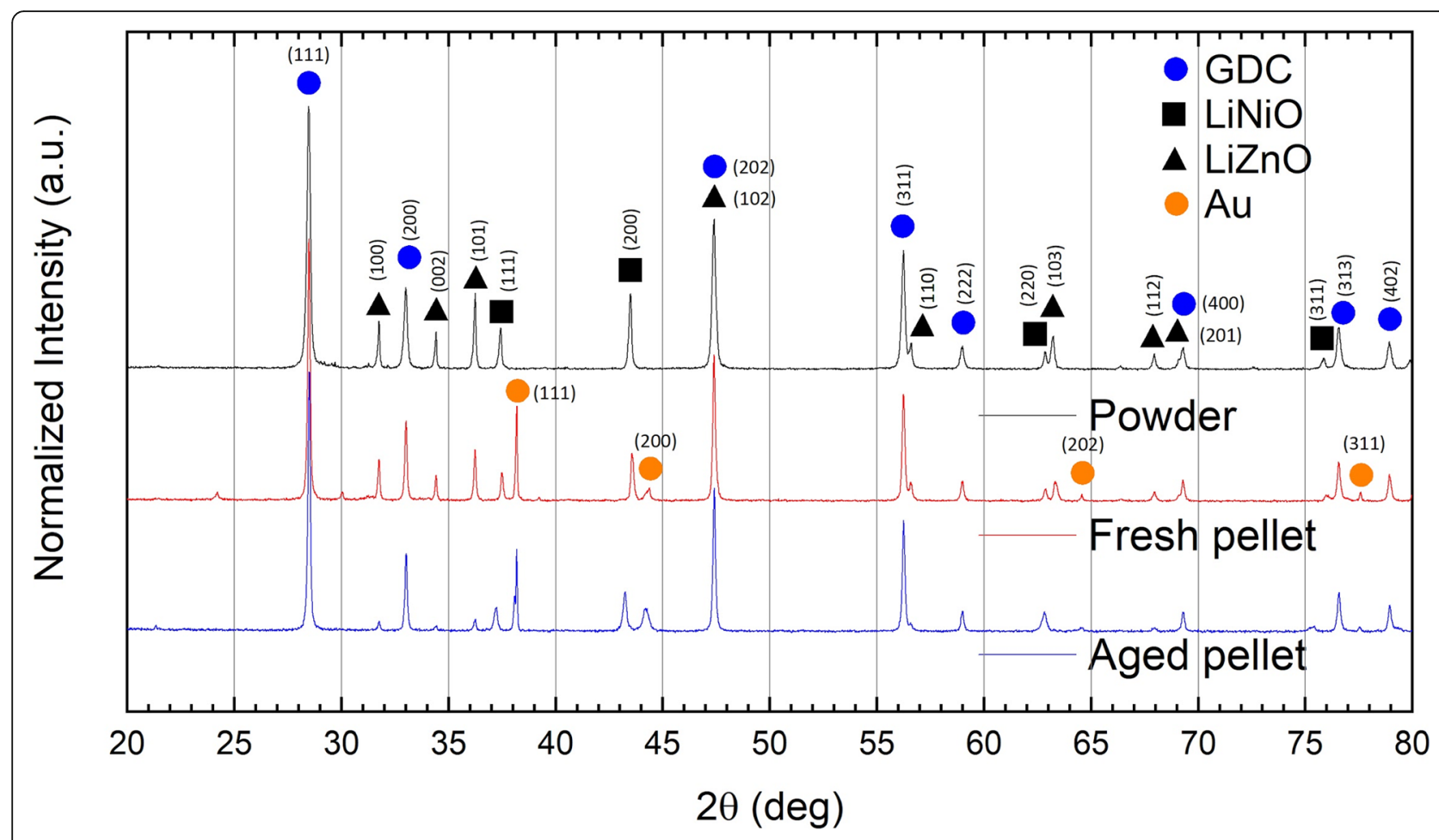

Fig. 4 XRD-spectra of LNZ-GDC-NLKC powder, fresh pellet, and aged pellet. Spectra intensities are normalized to the GDC (111) peak. Characteristic peaks of LNZ and GDC are clearly visible

cause in detail, but it was outside the scope of the present study.

Figure $6 \mathrm{~b}$ presents the impedance response of the SLFC at different temperatures from $500^{\circ} \mathrm{C}$ to $600^{\circ} \mathrm{C}$. The EIS plot consists of a tail at high frequency, overlapping semicircles at the intermediate frequencies and another tail at low frequency. The intercept of the semicircle with the real axis in the high frequency region shows the ohmic resistance of the cell. The overlapping semicircles in the intermediate frequency region are associated to the charge transfer process and mass transfer processes $[41,45-48]$. In this study, the focus was on the ionic conductivity of the SLFC and thus the quantitative EIS analysis is limited to the ohmic resistance. At

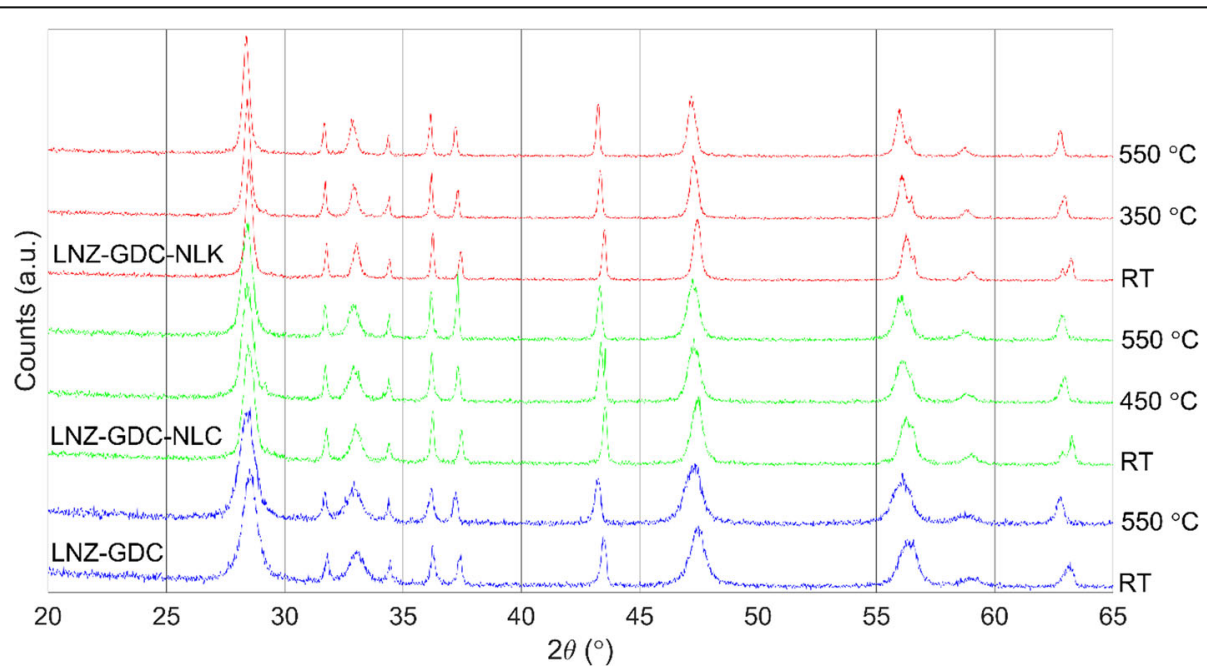

Fig. 5 XRD-spectra of LNZ-GDC, LNZ-GDC-NLC and LNZ-GDC-NLKC samples at room temperature, slightly below the melting temperatures of the binary and ternary eutectic mixtures of carbonates $\left(350^{\circ} \mathrm{C}\right.$ for NLKC and $450^{\circ} \mathrm{C}$ for NLC) and at $550^{\circ} \mathrm{C}$ 


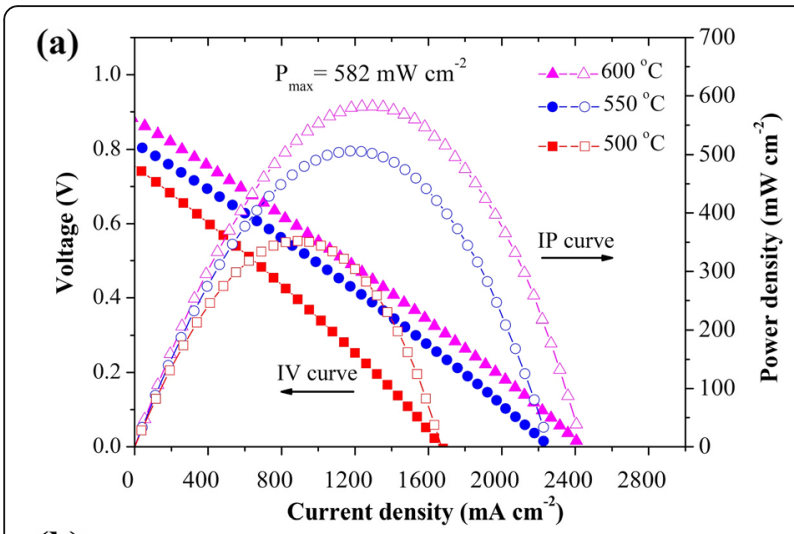

(b)

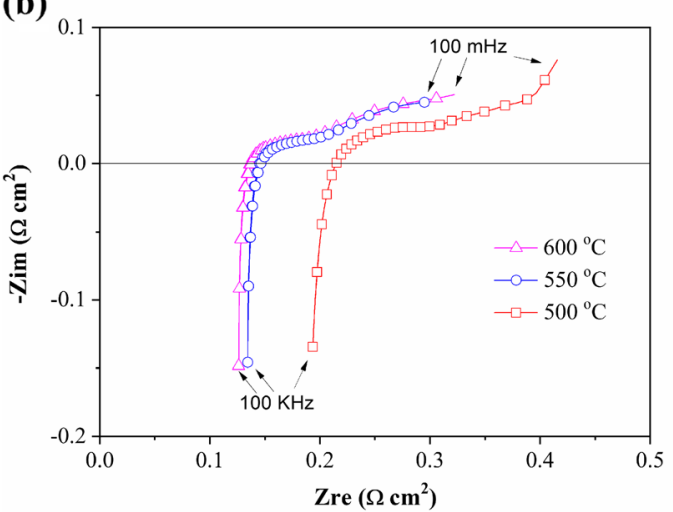

(c)

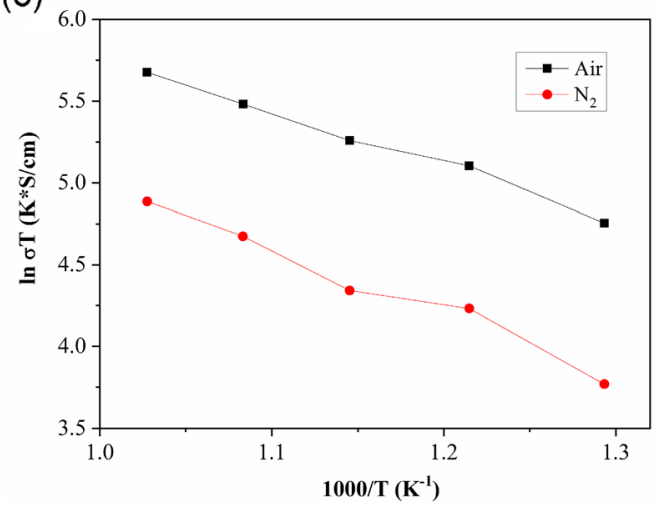

Fig. 6 I-V and I-P curves (a), EIS spectra (b) and ionic and electronic conductivity (c) of LNZ-GDC-NLKC SLFC at different temperatures

$500^{\circ} \mathrm{C}$, the ohmic resistance of the pellet was $0.22 \Omega$ $\mathrm{cm}^{2}$, which is much lower than that of the LNZ-GDC material (approx. $0.5 \Omega \mathrm{cm}^{2}$ at $550{ }^{\circ} \mathrm{C}$ [7]) due to the enhanced ionic conductivity of adding the carbonate. When the temperature was increased to $600^{\circ} \mathrm{C}$, the ohmic resistance was reduced further to $0.14 \Omega \mathrm{cm}^{2}$ since the ionic conductivity increases with temperature. The electrode polarization resistance decreased slightly when increasing the temperature from $500^{\circ} \mathrm{C}$ to $600^{\circ} \mathrm{C}$. The polarization losses were reasonably low.

As LNZ-GDC-NLKC is a mixture of electronic and ionic conductive materials, it is difficult to separate the ionic and electronic conductivity strictly in this mixed material. As shown in Fig. 6c, the conductivity of the material increases both in air and in nitrogen atmosphere with increasing temperature. The electrical conductivity of the component in air is about $0.22 \mathrm{~S} / \mathrm{cm}$ at $600{ }^{\circ} \mathrm{C}$, lower than that of pure GDC-NLKC material (about $0.55 \mathrm{~S} / \mathrm{cm}$ ) due to addition of LNZ. In a $\mathrm{N}_{2}$ atmosphere, the conductivity (mainly electronic conductivity) is around $0.088 \mathrm{~S} / \mathrm{cm}$ at $600{ }^{\circ} \mathrm{C}$, which is beneficial to avoid short-circuiting. The combination of LNZ-GDC and carbonates balanced the ratio of electronic and ionic conductivity reflecting positively to the performance. The balance of ionic and electronic conductivity by adding a material with higher ionic conductivity alleviates the energy wasted by short circuiting [28].

A common concern with SLFC is its long-term stability [49]. A 10-h test of the LNZ-GDC-NLKC cell was performed at $\mathrm{OCV}$ at $600{ }^{\circ} \mathrm{C}$ to test the new material combination. Indeed the OCV dropped from its initial value, $0.92 \mathrm{~V}$, to $0.72 \mathrm{~V}$ after $7 \mathrm{~h}$ after which it stabilized. Meanwhile, the ohmic resistance of the cell increased from 0.15 to $0.22 \Omega \mathrm{cm}^{2}$. Based on the XRD in Figs. 4 and 5 the reason for the performance reduction is probably not in the chemical interaction between LNZ, GDC, and carbonates, but in the instability of the amorphous carbonate, which is in molten state at this temperature [40]. A long-term test was outside the scope of the present study, but would be beneficial to identify other possible sources for degradation and mechanical stability, as we observed cell cracking in some cells during thermal cycling. All the measurements reported here were done in stable conditions.

\section{Test with binary carbonate}

The effect of the ionic conductor composition was further investigated by changing the ternary to a binary carbonate $\left(\mathrm{Na}_{2} \mathrm{CO}_{3}: \mathrm{Li}_{2} \mathrm{CO}_{3}, \mathrm{NLC}\right)$ and reducing the carbonate content of the ionic conductor from $30 \mathrm{w}-\%$ to $25 \mathrm{w}-\%$. Similar 3:1 GDC-NLC mixture was reported as an electrolyte in a three-layer fuel cell [40]. The LNZGDC-NLC test cell was characterized at $550^{\circ} \mathrm{C}$ and $600{ }^{\circ} \mathrm{C}$ under $\mathrm{H}_{2}$ and air atmospheres (optimized gas flow rates were $100 \mathrm{ml} / \mathrm{min}$ both air and $\left.\mathrm{H}_{2}\right)$. At $600^{\circ} \mathrm{C}$, the LNZ-GDC-NLC fuel cell (Fig. 7a) achieved a power density of $243 \mathrm{~mW} / \mathrm{cm}^{2}$, which is less than half of that of the LNZ-GDC-NLKC cell $\left(582 \mathrm{~mW} / \mathrm{cm}^{2}\right)$. The difference can be explained by increased ohmic resistance: based on EIS, the values were $0.41 \Omega \mathrm{cm}^{2}$ and $0.14 \Omega$ $\mathrm{cm}^{2}$ for the LNZ-GDC-NLC (Fig. 7b) and LNZ-GDCNLKC cells, respectively. Actually, the LNZ-GDC-NLKC cell yielded a better power density $\left(352 \mathrm{~mW} / \mathrm{cm}^{2}\right)$ and a lower ohmic resistance $\left(0.22 \Omega \mathrm{cm}^{2}\right)$ at $500{ }^{\circ} \mathrm{C}$ than the LNZ-GDC-NLC cell at $600^{\circ} \mathrm{C}$. 

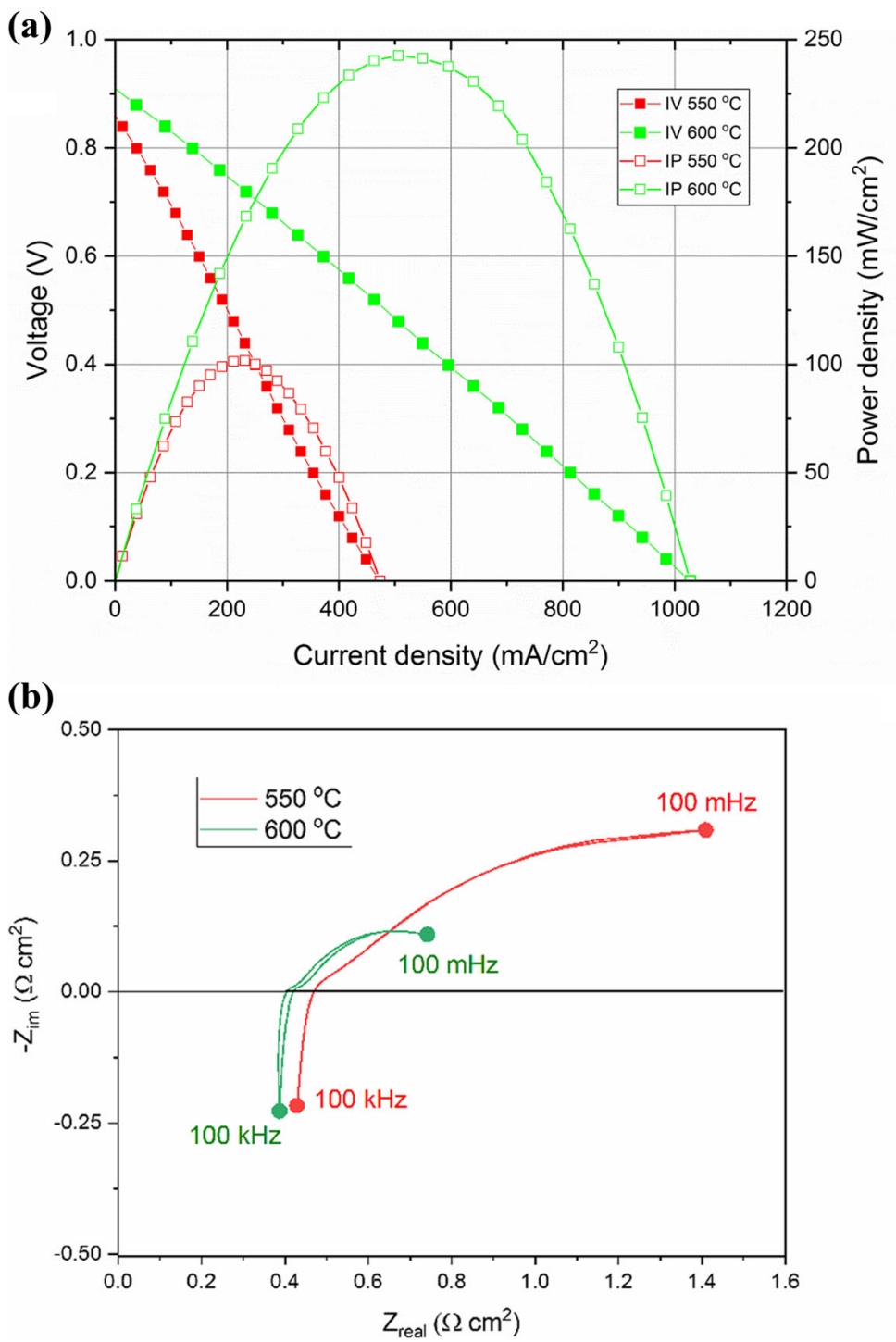

Fig. $7 \mathrm{IV}$ - and IP-curves (a) and EIS spectra (b) of the LNZ-GDC-NLC cell

The increase in ohmic resistance results from multiple factors. Using $25 \mathrm{w}-\%$ binary carbonate instead of $30 \mathrm{w}-$ $\%$ ternary carbonate obviously led to increased areaspecific resistivity of the ionic conductor due to reduced carbonate content and increased melting temperature. Also, the manufacturing procedures of the cells had some differences that has to be taken into account when comparing the cell performances. Most significantly, the thicknesses of the pellets were different: $1.0 \mathrm{~mm}$ for LNZ-GDC-NLKC and $1.5 \mathrm{~mm}$ for LNZ-GDC-NLC. The increase of area-specific resistance of LNZ-GDC material has been shown to be faster than linear when the pellet thickness is increased [7]. Increased thickness and reduced ionic conductivity together can explain the lower performance of the LNZ-GDC-NLC cell when compared to the LNZ-GDC-NLKC cell. However, it should be noted that there may be some other factors resulting from the manufacturing procedures that have a minor contribution to the results obtained.

\section{Conclusions}

A single-layer fuel cell consisting of lithium nickel zinc oxide (LNZ) as semiconducting material, gadoliniumdoped cerium oxide (GDC) as ionic conductor and a ternary carbonate $\mathrm{Na}_{2} \mathrm{CO}_{3}: \mathrm{Li}_{2} \mathrm{CO}_{3}: \mathrm{K}_{2} \mathrm{CO}_{3}(\mathrm{NLKC})$ as an ionic conduction enhancing additive was successfully fabricated and characterized. The fuel cell device reached a power density of $510 \mathrm{~mW} / \mathrm{cm}^{2}$ at $550{ }^{\circ} \mathrm{C}$ and $582 \mathrm{~mW} / \mathrm{cm}^{2}$ at $600^{\circ} \mathrm{C}$. Adding $30 \mathrm{w}-\%$ of NLKC to the GDC improved the ionic conductivity 15 -fold and the power density by more than 30 -fold. Replacing NLKC with a binary carbonate $\mathrm{Na}_{2} \mathrm{CO}_{3}: \mathrm{Li}_{2} \mathrm{CO}_{3}$ (NLC) dropped 
the performance to $243 \mathrm{~mW} / \mathrm{cm}^{2}$ at $600{ }^{\circ} \mathrm{C}$. The lower performance compared to NLKC can result from several factors, most importantly from the higher melting temperarture of the eutectic carbonate mixture and increased pellet thickness. However, also the NLC-based device confirmed the positive role of alkali carbonate mixture in improving the ionic conductivity and performance of a single-layer fuel cell. This work shows that the eutectic alkali carbonate mixtures, which have been used in three-layer fuel cells, can also be applied to SLFCs. The results achieved could thus help in improving the SLFC technology further.

The aging tests showed an initial decrease in the LNZGDC-NLKC cell performance, after which it stabilized. However, long-term stability tests in controlled environment would be recommended for future work to verify the practical usefulness of the carbonate-adding strategy. At the same time, investigating alternative strategies for improvement of the fuel cell such as using advanced fabrication techniques (e.g. Pulsed Laser Deposition) to produce thinner and mechanically rigid cells could be worthwhile to pursue.

\section{Supplementary information}

Supplementary information accompanies this paper at https://doi.org/10. 1186/s42500-020-00014-3.

Additional file 1 Figure S1. IV and IP cuve of the LNZ-GDC cell. Figure S2. lonic (black) and electronic (red) conductivities of LNZ-GDC-NLKC SLFCs at different temperatures. Figure S3. Difference between ionic and electronic conductivities of LNZ-GDC-NLKC SLFCs at different temperatures.

\section{Abbreviations \\ SLFC: Single-layer fuel cell; GDC: Gadolinium-doped cerium oxide; SDC: Samarium-doped cerium oxide; NCAL: $\mathrm{Ni}_{0.8} \mathrm{CO}_{0.15} \mathrm{Al}_{0.05} \mathrm{LiO}_{2-\mathrm{d}}$; NSDC: $\mathrm{Na}_{2} \mathrm{CO}_{3}$-SDC; LSCF: $\mathrm{La}_{0.6} \mathrm{Sr}_{0.4} \mathrm{CO}_{0.2} \mathrm{Fe}_{0.8} \mathrm{O}_{3-\mathrm{d}} ; \mathrm{BSCF}: \mathrm{Ba}_{0.5} \mathrm{Sr}_{0.5} \mathrm{Co}_{0.2} \mathrm{Fe}_{0.8} \mathrm{O}_{3-\mathrm{d}}$. LNZ: Li ${ }_{0.15} \mathrm{Ni}_{0.45} \mathrm{Zn}_{0.4} \mathrm{O} ; \mathrm{NLC}: \mathrm{Na}_{2} \mathrm{CO}_{3}: \mathrm{Li}_{2} \mathrm{CO}_{3} ; \mathrm{NLKC}: \mathrm{Na}_{2} \mathrm{CO}_{3}: \mathrm{Li}_{2} \mathrm{CO}_{3}: \mathrm{K}_{2} \mathrm{CO}_{3}$; OCV: Open circuit voltage; EIS: Electrochemical impedance spectroscopy; IV: Current-voltage; IP: Current-Power density; HT-XRD: High temperature X- ray diffraction; TEM: Transmission electron microscope}

\section{Acknowledgements}

We acknowledge the provision of facilities and technical support by Aalto University at OtaNano - Nanomicroscopy Center (Aalto-NMC). The financial support by the Academy of Finland (Grant No. 13279204) is greatly acknowledged. Ms. Xueli Yao thanks China Scholarship Council for their financial support. Dr. Asghar thanks the Hubei Talent 100 programme and Academy of Finland (Grant No. 13329016, 13322738) for their support.

\section{Authors' contributions}

S-J and Y-X performed the experiments. J-E helped with the analysis of the samples. W-L and AM-R contributed to the sample preparation. M-A was responsible for making the experimental design. P-L was responsible for advising the work, commenting and reviewing the manuscript. All authors contributed to the manuscript. The authors have read and approved the final manuscript.
}

\section{Funding}

The research work was primarily supported by Academy of Finland (Grant No. 13279204). China Scholarship Council provided financial support through a scholarship. Hubei Talent 100 programme and Academy of Finland (Grant No. 13329016, 13322738) also supported the work.

Availability of data and materials

The datasets of the current study are available from the corresponding authors on reasonable request.

\section{Competing interests}

The authors have no competing interests.

\section{Author details}

${ }^{1}$ New Energy Technologies Group, Department of Applied Physics, Aalto University School of Science, Fl-00076 Aalto, Finland. '2State Key Laboratory of Chemical Engineering, Tianjin Key Laboratory of Applied Catalysis, Science and Technology, School of Chemical Engineering, Tianjin University, Tianjin 300072, China. ${ }^{3}$ Collaborative Innovation Center of Chemical Science and Engineering (Tianjin), Tianjin 300072, China. ${ }^{4}$ Hubei Collaborative Innovation Centre for Advanced Organic Chemical Materials, Faculty of Physics and Electronic Science, Hubei University, Wuhan 430062, People's Republic of China. ${ }^{5}$ Department of Materials Science and Engineering, Aalto University School of Chemical Engineering, Fl-00076 Aalto, Finland. ${ }^{6}$ Institut für Energietechnik, Wasserstoff- und Kernenergietechnik, Technical University of Dresden, 01062 Dresden, Germany.

Received: 11 September 2019 Accepted: 28 April 2020

Published online: 19 May 2020

\section{References}

1. Zhu B, Fan L, Lund P. Breakthrough fuel cell technology using ceria-based multi-functional nanocomposites. Appl Energy. 2013;106:163-75.

2. Lu Y, Zhu B, Cai Y, Kim J-S, Wang B, Wang J, et al. Progress in electrolytefree fuel cells. Frontiers Energy Res. 2016:4:17.

3. Fan L, Wang C, Chen M, Zhu B. Recent development of ceria-based (nano) composite materials for low temperature ceramic fuel cells and electrolytefree fuel cells. J Power Sources. 2013;234:154-74.

4. He H, Huang X, Chen L. Sr-doped LalnO3 and its possible application in a single layer SOFC. Solid State Ion. 2000;130:183-93.

5. Zhu B, Ma Y, Wang X, Raza R, Qin H, Fan L. A fuel cell with a single component functioning simultaneously as the electrodes and electrolyte. Electrochem Commun. 2011;13:225-7.

6. Zhu B, Raza R, Abbas G, Singh M. An electrolyte-free fuel cell constructed from one homogenous layer with mixed conductivity. Adv Funct Mater. 2011;21:2465-9.

7. Asghar I, Jouttijärvi S, Jokiranta R, Valtavirta A-M, Lund P. Wide bandgap oxides for low-temperature single-layered nanocomposite fuel cell. Nano Energy. 2018;53:391-7.

8. Zhu B, Lund P, Raza R, Ma Y, Fan L, Afzal M, et al. Schottky junction effect on high performance fuel cells based on nanocomposite materials. Adv Energy Mater. 2015:5:1401895.

9. Zakaria Z, Hassan SHA, Shaari N, Yahaya AZ, Kar YB. A review on recent status and challenges of yttria stabilized zirconia modification to lowering the temperature of solid oxide fuel cells operation. Int J Energy Res. 2020; 44(2):631-50.

10. Yang $T$, Wen $Y$, Wu T, Xu N, Huang K. A highly active and Cr-resistant infiltrated cathode for practical solid oxide fuel cells. J Mater Chem A. 2020; $8: 82-6$.

11. Miao H, Chen W, Hu W, Wang H. Characterization and intermediate temperature solid oxide fuel cell performances of $\mathrm{BaCe}_{0.9} \mathrm{Tm}_{0,1} \mathrm{O}_{3-\alpha} \mathrm{KCL}$ NaCLcomposite electrolyte. Int J Electrochem Sci. 2019;14:4066-73.

12. Huang $P$, Horky A, Petric A. Interfacial reaction between nickel oxide and lanthanum Gallate during sintering and its effect on conductivity. J Am Ceram Soc. 1999:82:2402-6.

13. Zhu B, Qin H, Raza R, Liu Q, Fan L, Patakangas J, et al. A single-component fuel cell reactor. Int J Hydrogen Energy. 2011;36:8536-41.

14. Zhu B, Lund P, Raza R, Patakangas J, Huang Q-A, Fan L, et al. A new energy conversion technology based on nano-redox and nano-device processes. Nano Energy. 2013:2:1179-85.

15. Zhu B, Fan L, Zhao Y, Tan W, Xiong D, Wang H. Functional semiconductorionic composite GDC-KZnAl/LiNiCuZnO for single-component fuel cell. RSC Adv. 2014;4:9920-5. 
16. Zhu B, Raza R, Qin H, Fan L. Single-component and three-component fuel cells. J Power Sources. 2011;196:6362-5.

17. Zhang W, Cai Y, Wang B, Xia C, Dong W, Li J, et al. Mixed ionic-electronic conductor membrane based fuel cells by incorporating semiconductor $\mathrm{Ni}_{0.8} \mathrm{CO}_{0.15} \mathrm{Al}_{0.05} \mathrm{LiO}_{2-\delta}$ into the $\mathrm{Ce}_{0.8} \mathrm{Sm}_{0.2} \mathrm{O}_{2-\delta}-\mathrm{Na}_{2} \mathrm{CO}_{3}$ electrolyte. Int J Hydrogen Energy. 2016;41:15346-53.

18. Shao K, Li F, Zhang G, Zhang Q, Maliutina K, Fan L. Approaching durable single-layer fuel cells: promotion of Electroactivity and charge separation via Nanoalloy redox Exsolution. ACS Appl Mater Interfaces. 2019;11:27924-33.

19. Liu Y, Meng Y, Zhang W, Wang B, Afzal M, Xia C, et al. Industrial grade rareearth triple-doped ceria applied for advanced low-temperature electrolyte layer-free fuel cells. Int J Hydrogen Energy. 2017;42:22273-9.

20. Asghar I, Yao X, Jouttijärvi S, Hochreiner E, Virta R, Lund P. Intriguing electrochemistry in low-temperature single layer ceramic fuel cells based on $\mathrm{CuFe}_{2} \mathrm{O}_{4}$, accepted in international journal of hydrogen energy. In: Press; 2019.

21. Zhu B, Huang Y, Fan L, Ma Y, Wang B, Xia C, et al. Novel fuel cell with nanocomposite functional layer designed by perovskite solar cell principle. Nano Energy. 2016;19:156-64.

22. Zhu B, Wang B, Wang Y, Raza R, Tan W, Kim J-S, et al. Charge separation and transport in $\mathrm{La}_{0.6} \mathrm{Sr}_{0.4} \mathrm{CO}_{0.2} \mathrm{Fe}_{0.8} \mathrm{O}_{3-\delta}$ and ion-doping ceria heterostructure material for new generation fuel cell. Nano Energy. 2017;37:195-202.

23. Xia C, Wang B, Ma Y, Cai Y, Afzal M, Liu Y, et al. Industrial-grade rare-earth and perovskite oxide for high-performance electrolyte layer-free fuel cell. J Power Sources. 2016:307:270-9

24. Nie X, Chen Y, Mushtaq N, Rauf S, Wang B, Dong W, et al. The sintering temperature effect on electrochemical properties of $\mathrm{Ce}_{08} \mathrm{Sm}_{0.05} \mathrm{Ca}_{015} \mathrm{O}_{2-\delta}$ (SCDC) - La0.6Sr0.4Co0.2Fe0.803- $\delta$ (LSCF) heterostructure pellet. Nanoscale Res Lett. 2019;14:162.

25. Afzal M, Saleemi M, Wang B, Xia C, Zhang W, He Y, et al. Fabrication of novel electrolyte-layer free fuel cell with semi-ionic conductor $\left(\mathrm{Ba}_{0.5} \mathrm{Sr}_{0.5} \mathrm{Co}_{0.8} \mathrm{Fe}_{0.2} \mathrm{O}_{3-\delta}-\mathrm{Sm}_{0.2} \mathrm{Ce}_{0.8} \mathrm{O}_{1.9}\right)$ and Schottky barrier. J Power Sources. 2016;328:136-42.

26. Deng $\mathrm{H}$, Zhang $\mathrm{W}$, Wang $\mathrm{X}$, Mi Y, Dong $\mathrm{W}$, Tan $\mathrm{W}$, et al. An ionic conductor $\mathrm{Ce}_{0.8} \mathrm{Sm}_{0.2} \mathrm{O}_{2-\delta}$ (SDC) and semiconductor $\mathrm{Sm}_{0.5} \mathrm{Sr}_{0.5} \mathrm{CoO}_{3}$ (SSC) composite for high performance electrolyte-free fuel cell. Int J Hydrogen Energy. 2017;42: 22228-34.

27. Deng H, Feng C, Zhang W, Mi Y, Wang $X$, Dong $W$, et al. The electrolytelayer free fuel cell using a semiconductor-ionic $\mathrm{Sr}_{2} \mathrm{Fe}_{1.5} \mathrm{Mo}_{0.5} \mathrm{O}_{6-\delta}$ $\mathrm{Ce}_{0.8} \mathrm{Sm}_{0.2} \mathrm{O}_{2-\delta}$ composite functional membrane. Int J Hydrogen Energy. 2017:42:25001-7.

28. Dong $X$, Tian $L$, Li J, Zhao $Y$, Tian $Y$, Li Y. Single layer fuel cell based on a composite of $\mathrm{Ce}_{0.8} \mathrm{Sm}_{0.2} \mathrm{O}_{2-\delta}-\mathrm{Na}_{2} \mathrm{CO}_{3}$ and a mixed ionic and electronic conductor $\mathrm{Sr}_{2} \mathrm{Fe}_{1.5} \mathrm{MO}_{0.5} \mathrm{O}_{6-\delta}$. J Power Sources. 2014;249:270-6.

29. Li P, Yu B, Li J, Yao X, Zhao Y, Li Y. A single layer solid oxide fuel cell composed of $\mathrm{La}_{2} \mathrm{NiO}_{4}$ and doped ceria-carbonate with $\mathrm{H}_{2}$ and methanol as fuels. Int J Hydrogen Energy. 2016;41:9059-65.

30. Fan L, Zhu B, Su P-C, He C. Nanomaterials and technologies for low temperature solid oxide fuel cells: recent advances, challenges and opportunities. Nano Energy. 2018:45:148-76.

31. Fan $L, H e C$, Zhu B. Role of carbonate phase in ceria-carbonate composite for low temperature solid oxide fuel cells: a review. Int J Energy Res. 2017; 41:465-81.

32. Mi Y, Xia C, Zhu B, Raza R, Afzal M, Riess I. Experimental and physical approaches on a novel semiconducting-ionic membrane fuel cell. Int J Hydrogen Energy. 2018;43:12756-64.

33. Liu Y, Mushtaq N, Zhang W, Teng A, Liu X. Single-phase electronic-ionic conducting $\mathrm{Sm}^{3+} / \mathrm{Pr}^{3+} / \mathrm{Nd}^{3+}$ triple-doped ceria for new generation fuel cell technology. Int J Hydrogen Energy. 2018:43:12817-24.

34. Boden A, Di J, Lagergren C, Lindbergh G, Wang C. Conductivity of SDC and $(\mathrm{Li} / \mathrm{Na})_{2} \mathrm{CO}_{3}$ composite electrolytes in reducing and oxidising atmospheres. J Power Sources. 2007;172:520-9.

35. Zhu W, Xia C, Ding D, Shi X, Meng G. Electrical properties of ceria-carbonate composite electrolytes. Mater Res Bull. 2006;41:2057-64.

36. Zhu B, Mat M. Studies on dual phase ceria-based composites in electrochemistry. Int J Electrochem Sci. 2006;1:383-402.

37. Wang XD, Ma Y, Li SH, Kashyout AH, Zhu B, Muhammed M. Ceria-based nanocomposite with simultaneous proton and oxygen ion conductivity for low-temperature solid oxide fuel cells. J Power Sources. 2011;196:2754-8.

38. Zhao Y, XU Z, Xia C, Li Y. Oxide ion and proton conduction in doped ceriacarbonate composite materials. Int J Hydrogen Energy. 2013;38:1553-9.
39. Zhu B. Functional ceria-salt-composite materials for advanced ITSOFC applications. J Power Sources. 2003;114:1-9.

40. Asghar I, Jouttijärvi S, Jokiranta R, Lund P. Remarkable ionic conductivity and catalytic activity in ceramic nanocomposite fuel cells. Int J Hydrogen Energy. 2018;43:12892-9.

41. Asghar I, Heikkilä M, Lund P. Advanced low-temperature ceramic nanocomposite fuel cells using ultra high ionic conductivity electrolytes synthesized through freeze-dried method and solid-route. Materials Today Energy. 2017;5:338-46.

42. Zhu B, Fan L, Deng H, He Y, Afzal M, Dong W, et al. LiNiFe-based layered structure oxide and composite for advanced single layer fuel cells. J Power Sources. 2016;316:37-43.

43. Hu H, Lin Q, Zhu Z, Liu X, Afzal M, He Y, et al. Effects of composition on the electrochemical property and cell performance of single layer fuel cell. J Power Sources. 2015;275:476-82.

44. Hu H, Lin Q, Zhu Z, Liu X, Zhu B. Time-dependent performance change of single layer fuel cell with $\mathrm{Li}_{0.4} \mathrm{Mg}_{0.3} \mathrm{Zn}_{0.3} \mathrm{O} / \mathrm{Ce}_{0.8} \mathrm{Sm}_{0.2} \mathrm{O}_{2-\delta}$ composite. Int J Hydrogen Energy. 2014;39:10718-23.

45. Nguyen $\mathrm{H}$, Kang M, Ham H, Choi S, Han J, Nam S, et al. A new cathode for reduced-temperature molten carbonate fuel cells. J Electrochem Soc. 2014; 161:F1458-67.

46. Lee C-G. Analysis of impedance in a molten carbonate fuel cell. J Electroanal Chem. 2016;776:162-9.

47. Yao X, Li P, Yu B, Yang F, Li J, Zhao Y, et al. Hydrothermally synthesized NiOsamarium doped ceria nano-composite as an anode material for intermediate-temperature solid oxide fuel cells. Int J Hydrogen Energy. 2017:42:22192-200.

48. Fan L, Wang C, Osamudiamen O, Raza R, Singh M, Zhu B. Mixed ion and electron conductive composites for single component fuel cells: I. Effects of composition and pellet thickness. J Power Sources. 2012;217:164-9.

49. Lund P, Zhu B, Li Y, Yun S, Nasibulin A, Raza R, et al. Standardized procedures important for improving single-component ceramic fuel cell technology. ACS Energy Letters. 2017;2:2752-5.

\section{Publisher's Note}

Springer Nature remains neutral with regard to jurisdictional claims in published maps and institutional affiliations.
Ready to submit your research? Choose BMC and benefit from:

- fast, convenient online submission

- thorough peer review by experienced researchers in your field

- rapid publication on acceptance

- support for research data, including large and complex data types

- gold Open Access which fosters wider collaboration and increased citations

- maximum visibility for your research: over $100 \mathrm{M}$ website views per year

At BMC, research is always in progress.

Learn more biomedcentral.com/submissions 